\title{
Isoproturon: A Controversial Herbicide Hard to Confine in a Global Market
}

\author{
Raffaella Leoci ${ }^{1} \&$ Marcello Ruberti ${ }^{2}$ \\ ${ }^{1}$ Department of Emergency and Organ Transplant (D.E.T.O.), Section of Veterinary and Animal Production, \\ University of Bari Aldo Moro, Bari, Italy \\ ${ }^{2}$ Department of Economic Sciences, University of Salento, Lecce, Italy \\ Correspondence: Prof. Marcello Ruberti, Department of Economic Sciences, University of Salento, 73100 Lecce, \\ Italy. Tel: 39-8-3229-8746. E-mail: marcello.ruberti@unisalento.it
}

Received: August 24, 2020

Accepted: October 4, 2020

Online Published: October 12, 2020

doi:10.5539/jsd.v13n6p43

URL: https://doi.org/10.5539/jsd.v13n6p43

\begin{abstract}
Until the first decade of 2000, isoproturon (IPU), a controversial and potentially hazardous chemical substance for animals, was one of the herbicides most commonly used in agriculture around the world. The current scarcity of scientific studies about its toxicity is evident, especially as regards the possible dangerous consequences on higher mammals and humans and the long-term effects on environment, other animals and plant organisms. Contrary to what happened for other categories of herbicides (in particular, clomazone and glyphosate), in some States the precautionary principle prevailed, prohibiting its use. However, this prohibition does not seem sufficient because IPU is still used in many countries and it also reaches other nations where it is banned in the form of contaminated agro-food products. This is one of the lesser-known consequences of the global markets.
\end{abstract}

Keywords: Isoproturon, IPU, urea, herbicide, hazardous, properties, toxicity, animals, mammals, health, EU regulations, agriculture, prohibition

\section{Introduction}

Polyurea, phenylurea, thiourea or, generally as a whole, urea are a group of compounds, derived from urea, which find different uses. Some of them are used for the general control of weeds in agricultural practices (Gupta, 2019). "N,N-dimethyl-N'-(4-chlorophenyl)-urea" was the first of these herbicides, introduced in 1952 by the multinational DuPont as Monuron (Parette et al., 2015). Giessbuhler et al. (1975) published the first complete review of ureas, showing the possibility of using some of them as herbicides. On 1992, Giessbuhler and Voss showed that some ureas had similar pathways of transformation in soils, plants and animals, especially for the reactions of phase $I$. Due to the possibility of using them as herbicides, in the following years, they were synthesized many other compounds derived from urea. Currently more than 20 types of ureas are available, proposed as herbicides, with different names (Gupta, 2019). Isoproturon (IPU) was introduced as herbicide for controlling the selective germination of broadleaf weeds and long leaf herbs, in crops such as wheat, cereals, sugar cane, citrus fruits, cotton and asparagus (Liu, 2010).

Until the first decade of 2000, IPU was one of the herbicides most commonly used in agriculture around the world (Sørensen et al., 2003; Yin et al., 2008). Until the late 1900s it was used in the United States to control weeds. Its use was then prohibited. Until 2016 it was sold in 22 European countries. IPU consumption in France exceeded one thousand tons per year, placing it among the fifteen most used plant protection products in the country. In Italy, the registration decrees of all isoproturon-based products (eg Arelon, Clonel, Tolkan, Graminon, Erbogil, Isolin, Protugan, etc.), marketed by many companies (Aventis Cropscience, Sygenta, Sipcam, Griffin, Bayer Cropscience, Du Pont De Nemours, Basf, etc.) were revoked between 1991 and 2015. The Protugan marketed by the company Adama Italy and revoked 2015, was produced until 2017 to run out its stocks (Adama, 2016; Muller \& Applebyki, 2018).

The scarcity of studies about its toxicity is evident, especially as regards the possible dangerous consequences on higher mammals and humans and the long-term effects on environment, other animals and plant organisms. Contrary to what happened for other categories of herbicides (in particular, clomazone and glyphosate), in some States the precautionary principle prevailed, prohibiting its use. However, this prohibition does not seem sufficient 
because IPU, a controversial and potentially hazardous chemical substance, is still used in many countries and it also reaches other nations where it is banned in the form of contaminated agro-food products. This is one of the lesser-known consequences of the global markets.

\section{Chemical and Physical Characteristics}

Isoproturon (IPU) or "N,N-dimethyl-N'-[4-(1-methylethyl)phenyl]urea" also "3-(4-isopropylphenyl)-1, 1dimethylurea", of the family of ureas, has the following structural formula:

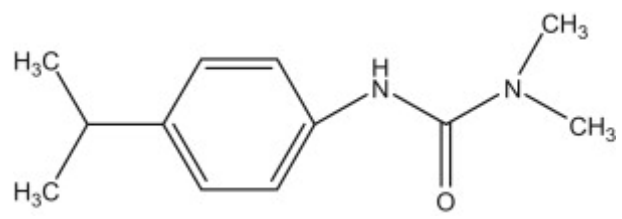

After phenol, IPU is one of the few derivatives of cumene of industrial importance. Cumene (isopropylbenzene) is obtained from benzene and propylene (Franck \& Stadelhofer, 1987). However, many other sources and processes are known to obtain IPU. Urea is usually obtained from carbon dioxide and ammonia. Typically, dimethylamine is produced by carrying out the reaction between methanol and ammonia in the gas phase at high temperature (about $400{ }^{\circ} \mathrm{C}$ ), by catalysts such as alumina or alumina silica, capable of causing dehydration and amination. Phosgene is obtained by reacting chlorine and carbon monoxide (Ryan et al., 2020). The latter is mainly obtained from methane steam reforming. Chlorine is obtained in turn by various methods from a sodium chloride solution (chlorine-soda process). Methanol is normally obtained by methane reforming (Crompton, 2019). In summary, the starting raw materials to produce IPU are methane and sodium chloride. Nitrogen (and therefore ammonia) is obtained from the air (Haber-Bosch synthesis), sodium chloride from the sea (Zhang et al., 2019).

The processes for the industrial production of IPU are covered by many patents: US Patents: 2655447 (1953 at du Pont), 4295877 (1981 at Philagro), 4840661 (1989 at Bayer Aktiengesellschaft), 4840661A (1992 at Bayer AG), 5847146A (1998 at Rainer Schutze Hoechst Schering Agrevo); Belgium Patent 770928 (1971 to Pepro); Canadian Patent no. 1115720A (1977 to Fisons Ltd.). Interesting is a method (CN1063279A) issued in 1992 to Shandong Normal University (China). Application CN92106419 proposed a process without the use of phosgene that is a very toxic and dangerous substance. The only raw material provided is urea and the process is considered even less expensive than that based on phosgene.

IPU occurs in the solid state in the form of colourless or white crystals tending to yellow. It has a melting point of $155^{\circ} \mathrm{C}$ and a vapour pressure of $0.003 \times 10^{-3} \mathrm{~Pa}$ at $20^{\circ} \mathrm{C}$. The solubility in water, at $22{ }^{\circ} \mathrm{C}$, is $65 \mathrm{mg} / \mathrm{L}$. Still in water, the half-life is 1,210 days (at pH 5), 1,560 days (at pH 7) and 540 days (at pH 9). Others (DoE, 1989) report 15 days as half-life in water $(\mathrm{pH} 7)$. At $20^{\circ} \mathrm{C}$ the dissolution in methanol is $75 \mathrm{~g} / \mathrm{L}$ (in dichloromethane), $63 \mathrm{~g} / \mathrm{L}$ (in acetone), $38 \mathrm{~g} / \mathrm{L}$ (in benzene), $5 \mathrm{~g} / \mathrm{L}$ (in xylene), $4 \mathrm{~g} / \mathrm{L}$ (in n-hexane). Subjected to combustion, IPU emits toxic fumes containing nitrogen oxides $\left(\mathrm{NO}_{\mathrm{x}}\right)$ and carbon oxides $\left(\mathrm{CO}\right.$ and $\left.\mathrm{CO}_{2}\right)$. It is extremely stable to the action of acids, alkalis and light (MacBean, 2009). It decomposes if subjected to the action of alkalis and heat (Loccufier et al., 2020).

This herbicide does not stay on plants and in the soil for long time. There are many studies (El-Sebai et al., 2011; Grundmann et al., 2011; Si et al., 2011; Hussain et al., 2015) on degradation processes in different environmental conditions and in various types of soils: it fragments giving different metabolites. Degradation occurs first through demethylation that leads to "monodemethyl isoproturon" (MDIPU) and "didemethyl isoproturon" (DDIPU) (Renyi et al., 2017). Furthermore, the side chain of phenylurea hydrolyzes giving rise to 4-IA, the aniline metabolite of the IPU (Hussain et al., 2009).

When it is introduced into the different types of soils, it degrades under the action of different factors (hydrolysis, photodegradation, biodegradation, etc.): i.e., by hydrolysis of phenylurea and demethylation of urea nitrogen. On soils, its half-life is around 40 days at an average ambient temperature of $20^{\circ} \mathrm{C}$ (Kulshrestha \& Muckerjee, 1986).

Also for this herbicide, the "logKoc value" was calculated for 17 different types of soils (Boivin et al., 2005). IPU impregnates and retains organic colloids in solution up to a certain threshold. Below this threshold, it appears to mainly involve clays (Stangroom et al., 2000). The adsorption of IPU in soils occurs in three ways: in solution; linked to insoluble matter; adsorbed to suspended organic colloids (Worrall et al., 1997). The most frequent Koc value (1.5) suggests that the herbicide has moderate mobility in the soil (Tahir et al., 2016).

\section{Authorizations}

It should be remembered that pesticides derive from significant Research\&Development efforts by big multinational agro-pharmaceutical companies. Their trade is subject to authorization by public administrations of 
many countries, which regulate their safe use in agricultural practices, identifying, for each active ingredient or formulation prepared for commercial purposes, any hazards for humans, animals and environment.

In Europe, the evaluation of pesticides was regulated by Directive 91/414/EEC, updated several times and finally replaced by Regulation 2009/1107/EC, that harmonizes the certification procedures between the member countries EFSA (European Food Safety Authority) is responsible for evaluating pesticides at EU level. If EFSA's opinion is favourable, the product is included in Annex I of Regulation 1107/2009/EC. However, the trade authorization is under the responsibility of each EU Member State, which issues it on the basis of EU recommendations and of EFSA valuation. Three dossiers must be attached to the applications for authorization of pesticides: (i) the scientific dossier, according to the Regulation 1107/2009/EC following the standard methods of control and testing; (ii) the toxicological dossier which provides information on the toxicity of pesticides; (iii) the biological file which provides residual information about efficiency, resistance by weeds and selectivity.

As regards IPU, for registration in Annex I to Directive 91/414/EEC, then in force, according to the provisions of Regulations 3600/92/EEC and 993/94/EC, Germany as a Member State prepared at the time a Monograph (EU, 1999). The applicants for registration were Rhône-Poulenc Agrochimie S.A. of Lyone, Hoechst Schering AgrEvo GmbH in Frankfurt am Main, the Makhteshim, ICC AGAN Brussels, the Barclay Chemicals (R\&D) Ltd. of Dublin, the Griffin (Europe) S.A. Neuchatel, Oxon's Dow AgroSciences, Phytorus S.A. of Emerainville, Montari Industries Ltd. of New Delhi and Gharda Chemicals Ltd. of Croydon Surrey. The manufacturers were RhônePoulenc/AgrEvo, Hoechst Schering AgrEvo GmbH, the Makhteshim Ashdod (Agan Chemical Manufacturers Ltd), the Barclay/Griffin (Prochrom Indústrias Químicas S/A Petroquimico de Camaçari, Copec, Camaçari, Brazil), Sanachem (PTY) Ltd. of Durban South Africa, Phytorus/Montari (Prochrom Industries Quimicas SA, of Camaraci - Bahia - Brazil and Montari Industries Ltd, Bhai Mohan Singh Nagar, Toansa, Dist. Ropar of Punjab - India) and the Gharda (Bhai Mohan Singh Nagar of Toansa, Distt. Ropar - Punjab - India).

After carrying out the required procedures, the Commission, according to the Directive 2002/18/EC, included IPU in Annex I ("Active substances") to the aforementioned Directive of 1991 then in force. The substances included in this annex are considered approved by the Commission also, according to Regulation 2009/1107/EC, and are registered into the Annex of Regulation 2011/540/EC, which entered into force subsequently. As indicated in that Part A, the approval of IPU expired on $30^{\text {th }}$ June 2016.

The request for renewal of the inclusion in the aforementioned Annex I was submitted, according to article 4, to the Commission referred to in Regulation 1141/2010/EU, or to the "Execution Commission" as amended by Regulation 380/2013/EU, within the deadline set by this article, together with the additional dossiers required by article 9 of the same Regulation. The request was considered complete by the rapporteur Member State that set a "renewal assessment report" by delivering it to EFSA and the Implementing Commission on $28^{\text {th }}$ February 2014. This Commission had to indicate the procedure for renewing the authorization of active substances (31 pesticides), among which the IPU.

Following the received comments, EFSA had to request a consultation with experts in the fields of toxicology and ecotoxicology and had to take a decision about the possibility that IPU fulfilled the conditions mentioned by Regulation 1107/2009/EC. This Regulation presented new principles for the authorization of active substances in pesticides, excluding those substances having endocrine activity. According to another Regulation (no. 528 of 2012), the Commission had to issue its reasons by $13^{\text {th }}$ December 2015; this did not happen and in January the Court of the European Union accepted a Swedish appeal, admitting in fact that the EU Commission had failed to obligations. The General Court rejected the Commission's justifications that the delay was motivated by the criticisms raised against the scientific criteria proposed in the summer of 2013. However, there were suspicions that the definition of the scientific criteria for the determination of endocrine disruptors could have been to ban all 31 pesticides, creating problems for manufacturers.

There were also doubts that IPU could be included into the art. 4 of the aforementioned Regulation. As regards the scientific risk valuation, the studies on reproductive toxicity denoted that IPU could alter the endocrine system of mammals. Besides, IPU was categorised as a "Category 2 - carcinogen" and it was suggested to be categorized as a "Category 2 - reproductive toxicant". Consequently, the circumstances laid down in the provisional requirements of Annex II of Regulation 1107/2009/EC, relating to human health regarding the possibility of endocrine interference, were encountered.

Previously, in 1958 and 1963, the WHO international standards, then in force for drinking water, did not refer to IPU and those of 1971 suggested that the pesticide residues that could occur in community water supplies brought only a minimum contribution to the total daily intake of pesticides for the served population. IPU was not evaluated in the "Drinking Water Quality Guidelines", issued in 1984, but those from 1993 indicated that IPU in drinking 
water could have an effect on health for values above $0.009 \mathrm{mg} / \mathrm{L}$ (WHO, 2008). Other risks were long-term effects on birds, wild mammals, aquatic organisms (EFSA, 2015), algae and aquatic plants, as we will see later.

On $5^{\text {th }}$ August 2015, EFSA communicated to the Commission its conclusions regarding the possibility that IPU could encounter the criteria set out in the Regulation 1107/2009/EC (Article 4). EFSA concluded that an elevated long-term hazard from IPU was also recognized for birds, mammals and aquatic organisms.

The Commission therefore, on the $1^{\text {st }}$ June 2016, issued an implementing regulation (EU 2016/872), where it stated: "Based on these identified risks, it has not been established with respect to one or more representative uses of at least one plant protection product that the approval criteria provided for in Article 4 of Regulation (EC) No $1107 / 2009$ are satisfied. It is therefore appropriate not to renew the approval of IPU in accordance with Article 20(1)(b) of Regulation (EC) No 1107/2009".

Since 30th September 2016, two herbicides, amitrol and IPU, have been temporarily banned within the European Union, as endocrine disruptors that could interfere with the hormonal system, cause reproductive problems, infertility and fetal malformations. Amitrol, also known as aminotriazole, is banned in Italy, but widely used in ten EU countries although, according to EFSA, it has "growth effects potentially associated with thyroid disruption".

However, it should be remembered that due to its dangerous consequences on aquatic species, IPU was already banned in several nations comprising Italy, Canada, United States, Denmark, Australia, and others (Danish EPA, 1999) while it is still accepted in the United Kingdom, New Zealand and India (PAN, 2010).

\section{Effects on Plants and Environment and Decontamination}

As it seems, IPU is mainly absorbed by the roots and, to a lesser extent, by the cotyledons and leaves. When applied to the leaves, before reaching the place of action, it must overcome numerous obstacles such as the waxy layer of the leaves, the cell envelope, the membrane plasma and the chloroplast membrane (Giessbuhler et al., 1975; Preston, 1994). However, after absorption, it is transferred to the xylem and accumulated in the apex and in the leaf edge (Vothknecht \& Westhoff, 2001) causing oxidative stress.

The results are yellowing, chlorosis, lightening effects and finally the drying of floras (Caux et al., 1998; Mittler, 2002; Hassan \& Nemat-Alla, 2005; Yin et al., 2008). As for wheat, the selective activity of IPU was also attributed to different pathways of reactions (Archireddy \& Kirkwood, 1986).

IPU is spread in the environment mainly during its distribution as a herbicide, but dispersions can occur during production, storage and transport. Having a low propensity to be absorbed by the soils, it can come, by sliding or percolating, into water bodies, despite its solubility in water, as mentioned, is rather low. Consequently, it has been detected both in surface and underground waters, with global effects on ecosystems, fauna and humans, all less known than the effects on flora (Rioboo et al., 2001; Hussain, 2012).

Also some metabolites deriving from IPU are dangerous for invertebrate aquatic species (Mansour et al., 1999), for microbial colonies (Widelfalck, 2008), freshwater algae (Vallotton et al., 2009) and often genotoxic (chromosomal aberrations in bone marrow cells, for example, chromatid gaps, chromatid breaks, acentric fragments, chromatid exchanges, ring chromosomes, and metacentric chromosomes) for mammals (Swiss albino mice) (Behera \& Bhunya, 1990; Hoshiya et al., 1993; Peres et al., 1996). For example, it appears that the main IPU metabolite, 4-IA mentioned above, is more toxic than IPU (Tixier et al., 2002; Papadopoulou et al., 2016).

Considered the harmful effects of this herbicide and its metabolites, it was necessary to reduce their presence in agricultural soils and in the environment, in order to limit their dispersion and dangerousness. Numerous possible treatments were identified for their abiotic degradation for the purpose of remediation of polluted soils: some of them configurable among chemical treatments, others among physical ones such as photodecomposition, volatilization and incineration. Nevertheless, most of them were not and are not pertinent for low concentration widespread contamination due to costs, lower efficiency and generally because they are not very environmentally friendly. Therefore, taking into account the environmental concerns associated with IPU and other phenylureas, it became necessary to think other economic and safe methods, such as the bioremediation processes (Cox et al., 1996; Pieuchot et al., 1996; Hussain, 2012; Hussain et al., 2017).

Some (Abdel-Hamid et al., 2013) have studied the ability of enzymes, degrading lignin, to attack and degrade IPU. LiP (lignin peroxidase) and MnP (manganese-dependent lignin peroxidase), produced by the white rot fungus $\mathrm{P}$. chrysosporium, degraded the IPU during in vivo and in vitro experiments. Others (Vroumsia et al. 1996; Khadrani et al., 1999; Ronhede et al. 2007; Badawi et al., 2009; Coppola et al., 2010; Dwivedi et al., 2011) have studied the effects of other types of fungi and mycetes for the same purpose.

Chemical attacks include the use of jasmonic acids (or methyl-jasmonic acid - MeJA) and salicylic acid (SA), 
which apparently (European Commission, 1999) facilitate the detoxification and degradation of the IPU residues present in wheat plantations and other species of crops. Jasmonic acid (JA), as is known, is the main controllers of the growth and defence of plants in relation to environmental stress. However, the ways in which JA attends the accumulation/degradation processes of pesticides in plants are mostly unknown. Some researchers (Ma et al., 2018) have studied the MeJA contribution to degradation of IPU in wheat by subjecting Triticum aestivum plants to 4 $\mathrm{mg}$ of IPU per kg of plants (that is an environmentally realistic concentration). With this treatment the growth level and the concentration of chlorophyll were reduced. When the plants were covered by small amounts of MeJA $(0.1$ $\mu \mathrm{M})$, the phytotoxicity induced by IPU was significantly attenuated with an increase in the concentration of chlorophyll and a reduced level of damage to the cells. The concentration of IPU in plants and soil was also reduced while 12 compounds deriving from the same herbicide were detected.

Others (Liang \& Yang, 2012) have studied the function of the SA to reduce the IPU toxicity in wheat crops (Triticum aestivum). Plants that had been treated with $4 \mathrm{mg} / \mathrm{kg}$ of IPU showed reduced growth and damages of oxidation; however associated use of SA ( $5 \mathrm{mg} / \mathrm{L})$ mitigate the damage.

Another problem presented by IPU, like many other herbicides, is the loss of efficacy after repeated use (LeBaron \& Gressel J., 1982; De Prado et al., 1997; Preston, 2004; Bhullar et al., 2017). In the late 1900s it was noted in the North West of India (Haryana, Pinjab and western Uttar Pradesh) that wheat and rice yields were reduced due to the weed development of "Canary Island" common canary plants (Phalaris canariensis), which became resistant to action of IPU (Malik \& Singh, 1993).

Walia et al. (1997) carried out researches during the biennials 1993-94 and 1994-95 on different biotypes of Phalaris. Most of them were not controlled by IPU even using twice the recommended dose $(1.88 \mathrm{~kg} / \mathrm{ha})$ because plant populations had developed resistance to the herbicide. Other authors reported resistance to IPU by different biotypes of Phalaris minor. The resistance action of the plant can arise as a result of three mechanisms: prevention of the herbicide to act in the place of action, metabolic detoxification and resistance in the place of action (Tripati \& Gaur, 2014).

\section{Effects on Animals}

As with other pesticides, the available data about the effects of IPU on living organisms do not agree. Many studies and researches on the effects on animals, laboratory species, do not always agree with each other. Some tests show that they can be weakly mutagenic and in biological tests on rodents they have shown the possibility of inducing tumours in different organs (see a summary of the main researches reported below in the Table 1 of the Appendix Section).

Gupta et al. (2013) believe that some ureas are not very toxic to mammals. According to this study, for rats, the $\mathrm{LD}_{50}$ of diuron and IPU supplied orally is about $2900 \mathrm{mg} / \mathrm{kg}$. These compounds can cause irritation of skin and eyes at very low doses.

Of the same content are Hodgson and Meyer (1997), who, from the research carried out on some ureas in the first years of diffusion, consider them to possess low levels of toxicity, not dangerous if used normally, that is, at the recommended doses, with the exception of the tebutiuron, which can be slightly dangerous.

According to Liu (2010), some phenylureas used as herbicides, suspected of having some mutagenic effects, are not potentially carcinogenic. However, IPU could cause malformations in rats during sperm maturation and reduced spermatogenesis.

Others (Hoshiya et al., 1993; Orton et al., 2009) highlighted that in rats it causes liver tumors and increases the likelihood of tumor formation, also reporting that it possesses a potential ability to destroy the endocrine system, anti-estrogenic and antiandrogenic activity, production of ovulation and testosterone. Injections of $675 \mathrm{mg} / \mathrm{kg}$ of IPU on rats resulted in their death (Hazarika \& Sarkar, 2011).

Another study (Juliet et al., 1998) was carried out on goats to ascertain the ways of persistence and elimination of the herbicide after some days later from the oral administration of $500 \mathrm{mg} / \mathrm{kg}$ of the product. IPU was rapidly absorbed reaching the maximum in blood within 15 minutes. The maximum elimination rate of IPU through the faeces was reached after 48 hours and was no longer detected after 120 hours. The pattern of excretion of IPU through the urine resembled that of the blood and about 10-11\% was eliminated in the urine.

A concise presentation of the health problems presented by IPU is found in INRS data sheet of 2011. The toxicity of IPU in case of long-term oral exposure, according to this data sheet, had been tested on rodents, dogs and monkeys. The main target organs were the liver (enzyme induction, hepatomegaly, histological changes) and blood (hemolytic anemia). 
In rats, the oral absorption of IPU after a $50 \mathrm{mg} / \mathrm{kg}$ administration per gavage is rapid and significant $(90 \%)$. This level of absorption changes slightly during a single high dose administration $(500 \mathrm{mg} / \mathrm{kg})$ and during frequent administrations $(50 \mathrm{mg} / \mathrm{kg}$ for 14 days).

In rats, IPU (having carbonyl group labelled with radioactive carbon, ${ }_{14} \mathrm{C}$ ), orally administered, spreads throughout the body, with higher concentrations in the blood, liver and kidneys. Distribution is not affected by the dose administered or frequency (single or repeated dose). After 168 hours of administration, the radioactivity found in all organs does not exceed $0.6 \%$ of that administered. Repeated administration does not cause accumulation.

In rats, the metabolism of IPU is evident. The parent molecule is not found in the urine. The main metabolites derive from the oxidation of N-demethylation and isopropyl group. During oral administration, no conjugation reaction (glucide- or sulfur- conjugation) affects the metabolism of IPU. No splitting of the amide bond was identified and the absence of metabolites of aniline derivatives was clearly demonstrated. Elimination is rapid: it is completed within 3 days after administration. Most are eliminated in 24 hours mainly in the urine $(>85 \%)$, as metabolites.

Unlike animals, the effects on humans have not been the subject of many studies so far. For example, the possibility of IPU to cause cancer in humans has not been evaluated in the USA even in the context of the IRIS EPA program, the IARC (International Agency for Research on Cancer) and is not present in the "14 $4^{\text {th }}$ Report of the National Toxicology Program" on carcinogens. To get relevant news, it is necessary to go back to January $27^{\text {th }} 1996$, when about a ton of IPU was liberated, from a chemical plant near Frankfurt-Griesheim (Germany), into atmosphere due to an accident. A nearby residential area was polluted by different quantities up to a maximum in some areas of $500 \mathrm{mg} / \mathrm{m}^{2}$. According to published toxicological and contamination data, individual exposure remained below the LOEL (Lowest Observed Adverse Effect Level) in the following months. For better risk assessment, urine biomonitoring was offered to residents. HMEPMH (1-(4-(1-Hydroxy-1-methyl-ethyl)-phenyl)-3-methylharnstoff), the main metabolite of IPU was discovered in $12 \%$ of the test participants (19/154), with a maximum value of 14.2 $\mu \mathrm{g} / \mathrm{L}$ of urine, i.e. lower than the ADI (Acceptable Daily Intake) or to the "Tolerable daily dose" (reference dose in $\mathrm{mg} / \mathrm{kg} /$ day) (Bartram, 2015). Control tests showed a reduction in soil contamination after a few weeks and in June 1996 IPU was no longer detectable, in the soil plants and herbs of that area (Heudor \& Peters, 1997).

However, as already mentioned, subsequent ecotoxicological researches indicate that IPU and its metabolites seem to be carcinogenic and therefore dangerous for mammals, aquatic invertebrates, plants, freshwater algae and for microbial activity (Valloton et al., 2008; Orton et al., 2009).

\section{Discussion and Conclusions}

IPU, as mentioned, is no longer used in many countries and among them in Italy. Others, however, continue to use it, so that the herbicide can reach anywhere due to the international movement of goods.

With regard to the EU, note that the export and import procedures for agricultural products are governed by the Common Agricultural Policy (CAP). Depending on the nature and quantity of the imported goods, an "import license" (Agrim certificate) may be issued, which the operator (Italian or from other EU countries) must request from the Ministry of Foreign Trade. The release of the "Import authorization" is also provided following a phytosanitary inspection carried out in Italy by the competent "Phytosanitary Service by Region" (Legislative Decree no. 214 of $19^{\text {th }}$ August 2005). In addition to the "Certificate of origin", the importer must also have the "Phytosanitary Certificate" issued by the exporter.

Note that due to the Commission Implementing Regulation (EU) 2019/2072, some plants and plant products and other types of products (listed in Annexes XI and XII), which enter the EU must be accompanied by the aforementioned Phytosanitary Certificate which guarantees that they have been carefully inspected and that they are free from pests requiring quarantine measures and other types of pests and are in possession of the phytosanitary requirements provided for by the aforementioned Regulation. The national phytosanitary authorities of the exporting country issue the phytosanitary certificates. Once inside the EU, the Phytosanitary Certificate for plants, plant products and other imported objects that are listed in Annexes XIII and XIV of the aforementioned Regulation 2019/2072 / EU, can be replaced by a "passport of the plants", in compliance with the provisions of Regulation 2016/2031/EU and Implementing Regulation 2017/2313/EU. There are exceptions for a number of cases, listed in Annexes VI, VII, IX and XII Part C of the aforementioned Regulation, as the spread of dangerous organisms is considered excluded. For other exemptions, please refer to Article 15 of Directive 2000/29/EC and to Regulation 2004/1756/EC.

As regards pesticides, reference is made to Commission Regulation 2019/1792/EU, which entered into force on 18th May 2020, which reports the maximum residue levels, allowed in certain products, of some hazardous 
substances, including IPU. Among the recitals, in Point 2 it is recalled that "The approval of the active substance IPU was not renewed by the Commission Implementing Regulation (EU) 2016/872" and therefore it was necessary to delete the MRLs (Maximum Residue Levels) set for these substances in Annexes II and III of Regulation (EC) no. 396/2005. In whereas 4 of Commission Regulation (EU) 2019/1792 it is recalled that "the MRLs for these substances should be set at the relevant determination limit (LOD), in accordance with article 18 of Regulation (EC) no. 396/2005". In the annex to the Regulation in question (2019/1792) the "Residues and maximum residue levels ( $\mathrm{mg} / \mathrm{kg}$ ) of pesticides" for isoproturon are established equal to $0.01 \mathrm{mg} / \mathrm{kg}$ for a long series of products (fruit, vegetables, milk, coffee, eggs, honey, etc.).

In summary, it can be considered that studies of the consequences on the development of the rat of the administrations of doses from 100 to $500 \mathrm{mg} / \mathrm{kg}$ of body weight/day, showed effects of foetal toxicity of mammals during gestation, while with doses up to $100 \mathrm{mg} / \mathrm{kg}$ body weight/day, little or no foetotoxicity of the embryo. The overall NOAEL is around $80 \mathrm{mg} / \mathrm{kg}$ body weight/day. Studies on the development of rabbits, fed with doses up to $100 \mathrm{mg} / \mathrm{kg}$ of body weight/day, have also shown effects of maternal toxicity (reduction of body weight and food consumption), while with the administration of doses of foetus toxicity of the embryo (reduced foetal weight) of $160 \mathrm{mg} / \mathrm{kg}$ of body weight/day. The overall NOAEL is $50 \mathrm{mg} / \mathrm{kg}$ of body-offender weight/day.

In any case, the scarcity of studies conducted is evident, especially as regards the consequences on human organisms and the long-term effects on the environment and on animal and vegetable organisms. Contrary to what happened for other types of herbicides (in particular clomazone and glyphosate) it is clear that in some States the precautionary principle prevailed prohibiting the use of the product. But this prohibition does not seem sufficient because the same is still used in many countries and that with international trade, products grown in areas polluted with the herbicide may arrive. European consumers should be guaranteed by the phytosanitary certificate issued by the exporting countries, especially by those who continue to use the herbicide. It is easy to imagine the great work that the analysis laboratories must carry out to ascertain that the dozens of IPU formulas are absent, or present within the limits allowed, in the goods, especially of vegetable origin, which arrive at the customs.

It is clear that we have not got rid of IPU and will continue to deal with it until it has disappeared from the environment and until in states where it is still allowed to use it will not be declared illegal. It is one of the consequences of global markets and exchanges.

\section{References}

Abdel-Hamid, A., Solbiati, J., \& Cann, I. K. O. (2013). Insights into Lignin Degradation and its Potential Industrial Applications. Advances in Applied Microbiology, 82, 1-28. https://doi.org/10.1016/B978-0-12-4076792.00001-6

Adama. (2016). Isoproturon Position on Classification for Reproductive Toxicity. Expert Statement. Document Reference No. $9001952225^{\text {th }}$ January 2016.

Alletto, L., Coquet, Y., Benoit, P., \& Bergheaud, V. (2006). Effects of temperature and water content on degradation of isoproturon in three soil profiles. Chemosphere, 64(7), 1053-1061. https://doi.org/10.1016/j.chemosphere.2005.12.004

Amita, B., Anjali, S., Srivastava, A., Bali, R., Srivastava, P., \& Govindra, S. (2005). Effect of temperature on adsorption-desorption of isoproturon on a clay soil. Indian Journal of Weed Science, 37(3-4), 247-250.

Archireddy, N. R., \& Kirkwood, R. C. (1986). The foliar uptake of isoproturon by wheat and Alopecurus myosuroides huds. Pesticide Science, 17, 53-56. https://doi.org/10.1002/ps.2780170107

Badawi, N. et al. (2009). Metabolites of the phenylurea herbicides chlorotoluron, diuron, isoproturon and linuron produced by the soil fungus Mortierella sp. Environmental Pollution, 157(10), 2806-2812. https://doi.org/10.1016/j.envpol.2009.04.019

Bartram, J. (Ed.). (2015). Routledge Handbook of Water and Health. Routledge, London and New York. https://doi.org/10.4324/9781315693606

Behera, B. C., \& Bhunya, S. P. (1990). Genotoxic effectof isoproturon (herbicide) as revealed by three mammalian in vivo mutagenic bioassay. Indian Journal of Experimental Biology, 28(9), 862-867.

Bhullar, M. S., Kaur, N., Kaur, P., \& Gill, G. (2017). Herbicide resistance in weeds and its management. Agriculture Research Journal, 54(4), 436-444. https://doi.org/10.5958/2395-146X.2017.00085.0

Boivin, A., Cherrier, R., \& Schiavon, M. (2005). A Comparison of Five Pesticides Adsorption and Desorption Proces-ses. Chemosphere, 61(5), 668-76. https://doi.org/10.1016/j.chemosphere.2005.03.024 
Caux, P. Y., Kent, R. A., Fan, G. T., \& Grande, C. (1998). Canadian water quality guidelines for linuron. Environmental Toxicology and Water Quality, 13, 1-41. https://doi.org/10.1002/(SICI)10982256(1998)13:1<1::AID-TOX1>3.0.CO;2-B

Commission Implementing Regulation (EU) 2016/872 of $1^{\text {st }}$ June 2016 concerning the non-renewal of approval of the active substance isoproturon, in accordance with Regulation (EC) No 1107/2009 of the European Parliament and of the Council concerning the placing of plant protection products on the market, and amending Commission Implementing Regulation (EU) No 540/2011.

Commission Implementing Regulation (EU) 2017/2313 of $13^{\text {th }}$ December 2017 setting out the format specifications of the plant passport for movement within the Union territory and the plant passport for introduction into, and movement within, a protected zone (OJ L 331, 14.12.2017).

Commission Implementing Regulation (EU) 2019/2072 of $28^{\text {th }}$ November 2019 establishing uniform conditions for the implementation of Regulation (EU) 2016/2031 of the European Parliament and the Council, as regards protective measures against pests of plants, and repealing Commission Regulation (EC) No 690/2008 and amending Commission Implementing Regulation (EU) 2018/2019.

Commission Regulation (EU) 2019/1792 of $17^{\text {th }}$ October 2019 amending Annexes II, III and V to Regulation (EC) No 396/2005 of the European Parliament and of the Council as regards maximum residue levels for amitrole, fipronil, flupyrsulfuron-methyl, imazosulfuron, isoproturon, orthosulfamuron and triasulfuron in or on certain products (OJ L 277, 29.10.2019).

Coppola, L., del Pilar Castillo, M., \& Vischettia, C. (2010). Degradationofisoproturonandbentazone inpeatandcompost-basedbiomixtures. Published on linein Wiley On line Library, Society of Chemical Industry.

Cox, L., Walker, A., \& Welc, S. J. (1996). Evidence for the accelerated degradation of isoproturon in soils. Pesticide Science, 48, 253-260. https://doi.org/10.1002/(SICI)1096-9063(199611)48:3<253::AIDPS466>3.0.CO;2-V

Crompton, T. R. (2019). Chapter 10 - Pesticides and herbicides in nonsaline waters. In "Determination of Toxic Organic Chemicals in Natural Waters, Sediments and Soils Determination and Analysis", 161-217, https://doi.org/10.1016/B978-0-12-815856-2.00010-2

De Prado, R., Jorrín, J., \& García-Torres, L. (Eds.). (1997). Weed and Crop Resistance to Herbicides. Springer Science. https://doi.org/10.1007/978-94-011-5538-0

Department of the Environment (DoE). (1989). Pesticides in water supplies. London (DoE Reference: WS/45/1/1).

Dwivedi, S., Singh, B. R., Al-Khedhairy, A. A., \& Musarrat, J. (2011). Biodegradation of isoproturon using a novel Pseudomonas aeruginosa strain JS-11 as a multi-functional bioinoculant of environmental significance. Journal of Hazardous Materials, 185(2-3), 938-944. https://doi.org/10.1016/j.jhazmat.2010.09.110

EFSA. (2015). Conclusion on the peer review of the pesticide risk assessment of the active substance isoproturon. EFSA Journal, 13(8), 4206. https://doi.org/10.2903/j.efsa.2015.4206

El-Sebai, T., Devers-Lamrani, M., Lagacherie, B., Rouard, N., Soulas, G., \& Martin-Laurent, F. (2011). Isoproturon mineralization in an agricultural soil: Impact of temperature and moisture content. Biology and Fertility of Soils, 47(4), 427-435. https://doi.org/10.1007/s00374-011-0549-1

El-Sebai, T., Lagacherie, B., Cooper, J. F., Soulas, G., \& Martin-Laurent, F. (2005). Enhanced isoproturon mineralisation in a clay silt loam agricultural soil. Agronomy for Sustainable Development, 25(2), 271-277. https://doi.org/10.1051/agro:2005003

Ertli, T., Marton, A., \& Fol-denyi, R. (2004). Effect of pH and the role of organic matter in the adsorption of isoproturon on soils. Chemosphere, 57(8), 771-779. https://doi.org/10.1016/j.chemosphere.2004.07.009

Franck, H. G., \& Stadelhofer, J. W. (1987). Industrial Aromatic Chemistry: Raw Materials · Processes · Products. Springer-Verlag.

Giessbuhler, H., Martin, H., \& Voss, G. (1975). Herbicides, Chemistry, Degradation and Mode of Action (Vol. I, 2nd ed.). In Kearney P. C. A., \& Kaufman D. D. (Eds.), Marcel Dekker, NY.

Grundmann, S., Doerfler, U., Munch, J. C., Ruth, B., \& Schroll, R. (2011). Impact of soil water regime on degradation and plant uptake behaviour of the herbicide isoproturon in different soil types. Chemosphere, 82(10), 1461-1467. https://doi.org/10.1016/j.chemosphere.2010.11.037 
Gupta, P. K. (2014). Herbicides and fungicides. In R. C. Gupta (Ed.), Biomarkers in Toxicology. Academic Press, Elsevier Inc. https://doi.org/10.1016/B978-0-12-404630-6.00024-5

Gupta, P. K. (2019). Chapter 27 - Herbicides and Fungicides. In Biomarkers in Toxicology (2nd ed., pp. 477-499). https://doi.org/10.1016/B978-0-12-814655-2.00027-X

Gupta, R. C. (2017). Reproductive and Developmental Toxicology. Academic Press, Elsevier.

Gupta, R. C., \& Crissman, J. W. (2013). Safety Assessment including Current and Emerging Issues, in Toxicologic Pathology. In Haschek and Rousseaux's Handbook of Toxicologic Pathology (3rd ed.). Elsevier. https://doi.org/10.1016/C2010-1-67850-9

Hassan, N., \& Nemat-Alla, M. (2005). Oxidative stress in herbicide-treated broadbean and maize plants. Acta Physiologiae Plantarum, 27, 429-438. https://doi.org/10.1007/s11738-005-0047-x

Hazarika, A., \& Sarkar, S. (2001). Effect of isoproturon pretreatment on the biochemical toxicodynamics of anilofos in male rats. Toxicology, 165, 87-95. https://doi.org/10.1016/S0300-483X(01)00411-5

Heap, I. (2014). Herbicide resistant weeds. In Primentel, D., \& Peshin, R. (Eds.), Integrated Pest Management. Pesticide Problems (Vol. 3., pp. 281-303). Springer. https://doi.org/10.1007/978-94-007-7796-5_12

Heudor, U., \& Peters, M. (1997). Chemical accident with isoproturone in an industrial plant in Frankfurt am Main, 27 January 1996. Gesundheitswesen, 59(11), 661-616.

Hodgson, E., \& Meyer, S. A. (1997). Pesticides. In "Hepatic and gastrointestinal Toxicology". In McCluskey R. S., \& Earnest D. L. (Eds.), Comprehensive Toxicology. Pergamon, Oxford, UK.

Hoshiya, T., Hasegawa, R., Hakoi, K., Cui, L., Ogiso, T., Cabral, R., \& Ito, N. (1993). Enhancement by nonmutagenic pesticides of GST-P positive hepatic foci development initiated with diethylnitrosamine in the rat. Cancer Letters, 72, 59-64. https://doi.org/10.1016/0304-3835(93)90011-W

Hussain, S. et al. (2015). Abiotic and biotic processes governing the fate of phenylurea herbicides in soil: A review. Critical Reviews in Environment Science and Technology, 45, 1947-1998. https://doi.org/10.1080/10643389.2014.1001141

Hussain, S., Shahzad, T., Imran, M., Khalid, A., \& Arshad, M. (2017). Bioremediation of Isoproturon Herbicide in Agri-cultural Soils. In Singh S. (Ed.), Microbe-Induced Degradation of Pesticides. Environmental Science and Engineering. Springer, Cham. https://doi.org/10.1007/978-3-319-45156-5_4

Hussain, S., Sorensen, S. R., Devers-Lamrani, M., El-Sebai, T., \& Martin-Laurent, F. (2009). Characterization of an isoproturon mineralizing bacterial culture enriched from aFrench agricultural soil. Chemosphere, 77(8), 1052-1059. https://doi.org/10.1016/j.chemosphere.2009.09.020

INRS. (2011). Base de données Fiches Toxicologiques. Isoproturon Fiche toxicologique, (283), 2-3. Retrieved from www.inrs.fr/fichetox

Juliet, S., Mandal, T. K., Mal, B., Chowdhury, A., Bhattacharyya, A., \& Chakraborty, A. K. J. (1998). Metabolic Study of Isoproturon in Goats Following a Single Oral Administration: Toxicokinetics and Recovery. Journal of Agricultural and Food Chemistry, 46(1), 178-183. https://doi.org/10.1021/j9970284f

Khadrani, A., Seigle-Murandi, F., Steiman, R., \& Vroumsia, T. (1999). Degradation of three phenylurea herbicides (chlortoluron, iso-proturon and diuron) by micromycetes isolated from soil. Chemosphere, 38(13), 3041-3050. https://doi.org/10.1016/S0045-6535(98)00510-4

Kulshrestha, G., \& Muckerjee, S. K. (1986). The photochemical decomposition of the herbicide isoproturon. Pesticide science, 17, 289-494. https://doi.org/10.1002/ps.2780170506

Le Baron, H. M., \& Gressel, J. (1982). Herbicide Resistance in Plants. Wiley Interscience NYP.

Liang, L., Lu, Y. L., \& Yang, H. (2012). Toxicology of isoproturon to the food crop wheat as affected by salicylic acid. Environmental Science and Pollution Research (ESPR), 19(6), 2044-54. https://doi.org/10.1007/s11356-011-0698-7

Liu, J. (2010). Phenylurea Herbicides. In Krieger, R. (Ed.), Hayes' Handbook of Pesticide Toxicology (3rd ed., pp. 1725-1731). Section XII - Herbicides, Chapter 80. https://doi.org/10.1016/B978-0-12-374367-1.00080-x

Loccufier, E., Deventer, K., Manhaeghe, D., Van Hulle, S. W. H, \& De Clerck, K. (2020). Degradation kinetics of isoproturon and its subsequent products in contact with $\mathrm{TiO}_{2}$ functionalized silica nanofibers. Chemical Engineering Journal, 3871(5). https://doi.org/10.1016/j.cej.2020.124143 
Ma, L. Y., Zhang, S. H., Zhang, J. J., Zhang, A. P., Li, N., Wang, X. Q., ... Yang, H. (2018). Jasmonic Acids Facilitate the Degradation and Detoxification of Herbicide Isoproturon Residues in Wheat Crops (Triticum $\begin{array}{llll}\text { aestivum). } \quad \text { Chemical } & \text { Research }\end{array}$ https://doi.org/10.1021/acs.chemrestox.8b00100

MacBean, C. (2009). A World Compendium. The Pesticide Manual (15th ed.). BCPC, Alton, Hampshire, UK.

Malik, R. K., \& Singh, S. (1993). Evolving strategies for herbicide use in wheat: resistence and integrated weeds management. Proceedings International Symposium Indian Society Weed Science, 1, 225-238. Hisar.

Mansour, M., Feicht, E. A., Behechti, A., Schramm, K. W., \& Kettrup, A. (1999). Determination photostability of selected agrochemicals in water and soil. Chemosphere, 39, 575-585. https://doi.org/10.1016/S00456535(99)00123-X

Mendoza-Huizar, L. H. (2015). Chemical Reactivity of Isoproturon, Diuron, Linuron, and Chlorotoluron Herbicides in Aqueous Phase: A Theoretical Quantum Study Employing Global and Local Reactivity Descriptors. Journal of Chemistry. https://doi.org/10.1155/2015/751527

Mittler, R. (2002). Oxidative stress, antioxidants and stress tolerance. Trends in Plant Science, 7, 405-410. https://doi.org/10.1016/S1360-1385(02)02312-9

Muller, F., \& Applebyki, A. P. (2018). Weed Control, 2. Individual Herbicides. Ullmann's Encyclopedia of Industrial Chemistry, $7^{\text {th }}$ ed. (1999-2017). NY: John Wiley \& Sons.

Orton, F., Lutz, I., Kloas, W., \& Routledge, E. J. (2009). Endocrine disrupting effects of herbicides and pentachlorophenol: in vitro and in vivo evidence. Environmental Science \& Technology, 43(6), 2144-50. https://doi.org/10.1021/es8028928

Papadopoulou, E. S. et al. (2016). Dissipation and adsorption of isoproturon, tebuconazole, chlorpyrifos and their main transformation products under laboratory and field conditions. Science of the Total Environment, 1(569570), 86-96. https://doi.org/10.1016/j.scitotenv.2016.06.133

Parette, R. et al. (2015). Halogenated indigo dyes: A likely source of 1,3,6,8-tetrabromocarbazole and some other halogenated carbazoles in the environment. Chemosphere, 127(5), 18-26. https://doi.org/10.1016/j.chemosphere.2015.01.001

Peres, F., Florin, D., Grollier, T., Feurtet-Mazel, A., Coste, M., Ribeyre, F., ... Boudo, A. (1996). Effects of the phenylurea herbicide isoproturon on periphytic diatom communities in freshwater indoor microcosms. Environmental Pollution, 94, 141-152. https://doi.org/10.1016/S0269-7491(96)00080-2

Preston, C. (1994). Resistance of PS I disrupting herbicides. In Powels S. B., \& Holms J. A. M. (Eds), Herbicide resistance in plant (pp. 61-82). Lewis Publishers, Boca Raton.

Preston, C. (2004). Herbicide resistance in weeds endowed by enhanced detoxification: complications for management. Weed Science, 52(3), 448-453. https://doi.org/10.1614/P2002-168B

Regulation (EC) No 1107/2009 of the European Parliament and of the Council of $21^{\text {st }}$ October 2009 concerning the placing of plant protection products on the market and repealing Council Directives 79/117/EEC and 91/414/EEC) (OJ L 309. 24.11.2009).

Regulation (EC) No 396/2005 of the European Parliament and of the Council of $23^{\text {th }}$ February 2005 on maximum residue levels of pesticides in or on food and feed of plant and animal origin and amending Council Directive 91/414/EECText with EEA relevance (OJ L 70, 16.3.2005).

Regulation (EU) 2016/2031 of the European Parliament of the Council of $26^{\text {th }}$ October 2016 on protective measures against pests of plants, amending Regulations (EU) No 228/2013, (EU) No 652/2014 and (EU) No 1143/2014 of the European Parliament and of the Council and repealing Council Directives 69/464/EEC, 74/647/EEC, 93/85/EEC, 98/57/EC, 2000/29/EC, 2006/91/EC and 2007/33/EC (OJ L 317, 23.11.2016).

Renyi, L., Dörfler, U, Munch, J. C., \& Schroll, R. (2017). Enhanced degradation of isoproturon in an agricultural soil by a Sphingomonas sp. strain and a microbial consortium. Chemosphere, 168(2), 1169-1176. https://doi.org/10.1016/j.chemosphere.2016.10.084

Rioboo, C., Franqueira, D., Canle, M. L., Herrero, C., \& Cid, A. (2001). Microalgal Bioassays as a Test of Pesticide Photodegradation Efficiency in Water. Bulletin of Environmental Contamination and Toxicology, 67(2), 233238. https://doi.org/10.1007/s001280115 
Ronhede, S., Sorensen, S. R., Jensen, B., \& Aamand, J. (2007). Mineralization of hydroxylated isoproturon metabolites produced by fung. Soil Biology and Biochemistry, 39(7), 1751-1758. https://doi.org/10.1016/j.soilbio.2007.01.037

Ryan, T. A., Ryan, C., Seddon, E. A., \& Seddon, K. R. (2020). Phosgene and Related Carbonyl Halides, 5 Synthesis and formation of phosgene. Elsevier Ltd.

Sarkar, S. N., \& Gupta, P. K. (1993). Fetotoxic and teratogenic potential of substituted phenylurea herbicide, isoproturon in rats. Indian Journal of Experimental Biology, 31, 280-282.

Si, Y., Wang, M., Tian, C., Zhou, J., \& Zhou, D. (2011). Effect of charcoal amendment on adsorption, leaching and degradation of isoproturon in soils. Journal of Contaminant Hydrology, 123(1-2), 75-81. https://doi.org/10.1016/j.jconhyd.2010.12.008

Sørensen, S. R., Bending, G. D., Jacobsen, C. S., Walker, A., \& Aamand, J. (2003). Microbial degradation of isoproturon and related phenylurea herbicides in and below agricultural fields. FEMS Microbiology Ecology, 45(1), 1-11. https://doi.org/10.1016/S0168-6496(03)00127-2

Srivastava, M. K., \& Raizada, R. B. (1996). Developmental toxicity of the substituted phenylurea herbicide isoproturon in rats. Veterinary and human toxicology, 37(3), 220-23.

Stangroom, S. J., Lester, J. N., \& Collins, C. D. (2000). Abiotic behaviour of organic micropollutants in soilsand the aquatic environment. A review: I. Partitioning. Environmental Technology, 21(8), 845-863. https://doi.org/10.1080/09593332108618060

Tahir, M., Ul Hassan, A., Maqbool, S., Barber, B., Koskinen, W. C., Peng, X., \& Mulla, D. J. (2016). Sorption and Leaching Potential of Isoproturon and Atrazine in Low Organic Carbon Soil of Pakistan Under a WheatMaize Rotation. Pedosphere, 26(5), 687-698. https://doi.org/10.1016/S1002-0160(15)60077-7

Tixier, C., Sancelme, M., Ait-Aissa, S., Widehem, P., Bonnemoy, F., Cuer, A., ... Veschambre, H. (2002). Biotransformation of phenylurea herbicides by a soil bacterial strain, Arthrobac-ter sp N2: structure, ecotoxicity and fate of diuron metabolite with soil fungi. Chemosphere, 46, 519-526. https://doi.org/10.1016/S0045-6535(01)00193-X

Tripati, M. K., \& Gaur, A. K. (2014). Erbicide Resistance in Phalaris minor and Genetic Medication in Crop. In Gaur R. K., \& Sharma P. (Eds.), Approaches to Plant Stress and their Management (pp. 92). Springer India. https://doi.org/10.1007/978-81-322-1620-9_5

Vallotton, N., Eggen, R. I. L., \& Chèvre, N. (2008). Effect of Sequential Isoproturon Pulse Expo-sure on Scenedesmus vacuolatus. Archives of Environmental Contamination and Toxicology, 56(3), 442-449. https://doi.org/10.1007/s00244-008-9200-z

Vothknecht, U. C., \& Westhoff, P. (2001). Biogenesis and origin of thylakoid membranes. Biochimica et Biophysica Acta (BBA) - Molecular Cell Research, 1541(1-2), 91-101. https://doi.org/10.1016/S01674889(01)00153-7

Vroumsia, T., Steiman, R., Seigle Murandi, F., Benoit Guyod, J. L., \& Khadrani, A. (1996). Biodegradation of three substituted phenylurea herbicides (chlorotoluron, diuron, and isoproturon) by soil fungi. A comparative study. Chemosphere, 33(10), 2045-2056. https://doi.org/10.1016/0045-6535(96)00318-9

Walia, S. S., Brar, L. S., \& Dhaliwal, B. K. (1997). Resistance to isoproturon in Phalaris minor Retz. in Punjab. Plant Protein, 12, 138-40.

WHO. (1989). Isoproturon - Summary and evaluation of the toxicological data for isoproturon - Active ingredient technical. Unpublished report A 40025, submitted to WHO by Hoechst.

WHO. (2020). Re-evaluation of the toxicological properties of isoproturon and its safety in use. Unpublished report A27779, submitted to WHO by Ciba-Geigy, Hoechst, Rhône-Poulenc. Retrieved July 12, 2020, from http://origin.who.int/water_sanitation_health/water-quality/guidelines/2edvol2p2d.pdf

Widenfalk, A., Bertilsson, S., Sundh, I., \& Goedkoop, W. (2008). Effects of pesticides on community composition and activity of sediment microbes responses at various levels of microbial community organization. Environmental Pollution, 152, 576-584. https://doi.org/10.1016/j.envpol.2007.07.003

Worrall, F., Parker, A., Rae, J. E., \& Johnson, A. (1997). A Study of the Adsorption Kinetics of Isoproturon on Soil and Subsoil. Chemosphere, 34, 71-86. https://doi.org/10.1016/S0045-6535(96)00368-2 
Yin, X. L., Jiang, L., Song, N. H., \& Yang, H. (2008). Toxic reactivity of wheat (Triticum aestivum) plants to herbicide isoproturon. Journal of Agricultural and Food Chemistry, 56, 4825-483. https://doi.org/10.1021/jf800795v

Zhang, S., Zhao, Y., Shi, R., Waterhouse, G. I. N., \& Zhang, T. (2019). Photocatalytic ammonia synthesis: Recent progress and future. Energy Chemistry, 1(2), 100013. https://doi.org/10.1016/j.enchem.2019.100013

\section{Appendix}

Table 1. Summary table of the main adverse effects of IPU on mammals (rats)

\begin{tabular}{lcl}
\hline Effects & Doses $(\mathrm{mg} / \mathrm{kg})$ & \multicolumn{1}{c}{ Sources } \\
\hline Genotoxicity & $100,150,200$ & Behera \& Bhunya, 1990 \\
Liver tumors & 2000 & Hoshiya et al., 1993 \\
Hazards for endocrine system & 125,200 & Orton et al., 2009 \\
Death & 675 & Hazarika \& Sarkar, 2011 \\
Hemolytic anemia & 800 & INRS, 2011 \\
\hline
\end{tabular}

\section{Copyrights}

Copyright for this article is retained by the author(s), with first publication rights granted to the journal.

This is an open-access article distributed under the terms and conditions of the Creative Commons Attribution license (http://creativecommons.org/licenses/by/4.0/). 